\title{
Extended Radioligand Binding Profile of Iloperidone: A Broad Spectrum Dopamine/Serotonin/Norepinephrine Receptor Antagonist for the Management of Psychotic Disorders
}

\author{
Hans Otto Kalkman, Ph.D., Natarajan Subramanian, Ph.D., and Daniel Hoyer, Ph.D.
}

Iloperidone is a novel psychotropic compound currently undergoing Phase III trials. Its affinity for human dopamine and $5-\mathrm{HT}_{2 \mathrm{~A}}$ and $5-\mathrm{HT}_{2 \mathrm{C}}$ receptors has been reported previously (Kongsamut et al. 1996). This report presents the affinity of iloperidone for a largely extended number of human neurotransmitter receptors. In a few instances human receptors were not available and receptor studies were performed on tissues from laboratory animals. The present data, supplemented with those of Kongsamut et al. (1996), indicate that iloperidone displays high affinity $\left(K_{I}<\right.$ $10 \mathrm{nM}$ ) for norepinephrine $\alpha_{1}$-adrenoceptors, dopamine $D_{3}$ and serotonin $5-\mathrm{HT}_{2 A}$ receptors. Intermediate affinity (10$100 \mathrm{nM}$ ) was found for norepinephrine $\alpha_{2 \mathrm{C}}$-adrenoceptors, dopamine $D_{2 A}$ and $D_{4}$ receptors and serotonin $5-H T_{1 A}$,
5- $\mathrm{HT}_{1 B}, 5-\mathrm{HT}_{2 \mathrm{C}}$ and $5-\mathrm{HT}_{6}$ receptors. The affinity for all other receptors was below $100 \mathrm{nM}$, including norepinephrine $\alpha_{2 A}$, $\alpha_{2 B}, \beta_{1}$, and $\beta_{2}$, muscarine $M_{1}-M_{5}$, histamine $H_{1}$, dopamine $D_{1}$ and $D_{5}, C C K_{A}$ and $C C K_{B}, 5-H T_{7}$, dopamine and norepinephrine transporters. Thus, iloperidone targets a selective set of dopamine, norepinephrine and serotonin receptor subtypes. The affinity for this particular set of receptors indicates that iloperidone has the potential to be a broad spectrum antipsychotic, with efficacy against positive, negative, depressive and cognitive symptoms of schizophrenia, and a low propensity to induce side effects. [Neuropsychopharmacology 25:904-914, 2001] (C) 2001 American College of Neuropsychopharmacology. Published by Elsevier Science Inc.
KEY WORDS: Receptor binding profile; Psychotic disorders; Iloperidone; Adrenergic receptors; Dopamine receptors; Serotonin receptors

From the Novartis Pharma, Basel, Switzerland.

Address correspondence to: Dr. Hans Kalkman, Novartis Pharma, WSJ-360-405, CH-4002 Basel, Switzerland, Tel.: + 4161324 4304, Fax: + 4161324 5474, E-Mail: hans.kalkman@pharma.novartis.com

Received October 25, 2000; revised April 9, 2001; accepted April 24, 2001.

Online publication: 5/8/01 at www.acnp.org/citations/Npp 050801115 .
The prototypical classical neuroleptic agent haloperidol is an effective antipsychotic compound (Leucht et al. 1999) which, unfortunately, also induces severe extrapyramidal side effects (EPS) and hyperprolactinemia. The term "atypical antipsychotic" was originally introduced to describe compounds, such as clozapine, which not only suppressed psychotic symptoms, but differed from haloperidol by having a low tendency to induce EPS and increase plasma prolactin levels. It is postulated that dopamine $\mathrm{D}_{2}$ receptor blockade is the mechanism by which antipsychotic activity is achieved (Creese et al. 1976; Seeman et al. 1976). However, since 
clozapine also interacts with $\mathrm{D}_{2}$ receptors it is likely that there are additional properties embedded in the clozapine molecule that explain its "atypicality." One influential theory was put forward by Meltzer et al. (1989), who suggested that about a 10-fold higher affinity for serotonin $5-\mathrm{HT}_{2 \mathrm{~A}}$ over $\mathrm{D}_{2}$ receptors could be the key factor in achieving improved clinical response and absence of EPS. This hypothesis has led to the development of new antipsychotics with the desired $5-\mathrm{HT}_{2 \mathrm{~A}} / \mathrm{D}_{2}$ affinity ratio, although each of these compounds also binds to additional receptor sites. Several of these novel antipsychotic compounds indeed display clear benefits in terms of side-effect profile. Interestingly, clozapine is active in schizophrenic patients who are treatmentrefractory to other antipsychotics, including the more recent 5- $\mathrm{HT}_{2 \mathrm{~A}} / \mathrm{D}_{2}$ receptor antagonists (Wahlbeck et al. 1999; Conley et al. 1999; Taylor and Duncan-McConnell 2000). The elucidation of the multiple receptor interactions of clozapine suggested that other neurotransmitter systems may also play a role in the efficacy and tolerability of that molecule. Particularly, the antiadrenergic effects of clozapine are now receiving increased attention (Nutt 1994; Litman et al. 1996; Hertel et al. 1999). Iloperidone is a new psychotropic agent currently undergoing Phase III trials for the treatment of psychotic disorders (Figure 1). Iloperidone was selected from a large series of piperidinyl-benzisoxazoles because it showed a 300 -fold greater potency in a test for limbic activity (inhibition of apomorphine-induced climbing) than in a test for nigrostriatal activity (inhibition of apomorphine-induced stereotypy) (Strupczewski et al. 1995). The large difference of potency of iloperidone in these tests is expected to result in an improved ratio of therapeutic effect to EPS liability compared with standard antipsychotics.

Previous studies have investigated the receptor binding profile of iloperidone with rat receptors (Szewczak et al. 1995) and a limited number of human homologues of dopamine and 5-HT receptor subtypes (Kongsamut et al. 1996). These experiments demonstated that iloperidone displays the desired $5-\mathrm{HT}_{2 \mathrm{~A}} / \mathrm{D}_{2}$ affinity ratio. The aim of the present study was to determine the receptor affinity profile of iloperidone at a wider range of human neurotransmitter receptors. In

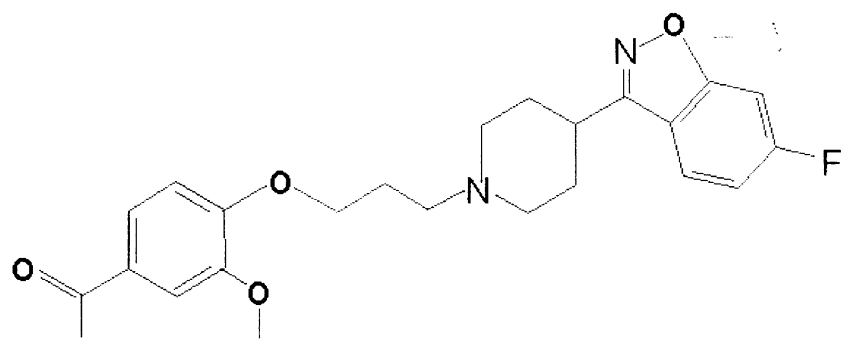

Figure 1. Chemical structure of iloperidone. resemblance to clozapine, it was noted that iloperidone possesses high affinity for norepinephrine $\alpha_{1}$ - and $\alpha_{2 C}$ adrenergic receptors.

\section{METHODS}

The radioligand receptor binding assays are listed in Table 1.

\section{Materials}

Radioligands were purchased from NEN Life Science Products, USA, except for ${ }^{3} \mathrm{H}-\mathrm{R} X 821002$ and ${ }^{3} \mathrm{H}-\mathrm{Me}-$ sulergine, which were obtained from Amersham Pharmacia Biotech Ltd, UK, and ${ }^{125}$ I-GTI which was obtained from ANAWA, Switzerland. Iloperidone was synthesized by Hoechst Marion Roussel. Unless specified otherwise, all other chemicals were of reagent grade and obtained through standard commercial sources.

\section{Membrane Preparation}

Total rat brain (minus cerebellum) membranes were purchased from Analytical Biological Services (ABS) and prepared according to the following customersupplied protocol. Male Wistar albino rats (250-300 g) were decapitated, the brains removed, the cerebral cortices dissected out and the rest of the brains homogenized in 10 volumes of ice-cold $50 \mathrm{mM}$ Tris- $\mathrm{HCl}$ buffer, $\mathrm{pH} 7.7$, for $30 \mathrm{~s}$. The homogenate was centrifuged at $1000 \mathrm{~g}$ for 10 minutes, the supernatant collected and centrifuged at $35,000 \mathrm{~g}$ for 10 minutes. The pellet was resuspended in buffer and washed by four further 10min centrifugations at $35,000 \mathrm{~g}$. The final pellet was resuspended in buffer ( $2 \mathrm{~mL} /$ brain) and aliquots $(2 \mathrm{~mL})$ were frozen and stored at $-80^{\circ} \mathrm{C}$. Prior to use, the membrane suspension was thawed quickly at $37^{\circ} \mathrm{C}$, centrifuged at $35,000 \mathrm{~g}$ for 10 minutes, washed once by suspension in the assay buffer and recentrifuged. The final pellet was resuspended and homogenized in the assay buffer to give the desired membrane concentration.

Guinea pig brain (minus cerebellum) membranes were also purchased from ABS and prepared according to the above protocol for rat brain membranes. The guinea pigs used were male Dunkin-Hartley with a 250-300 g body weight.

Calf brains were obtained from the local slaughterhouse and the caudate dissected over ice. Membranes were prepared as described previously (Bruinvels et al. 1992).

Cell membranes from Chinese hamster ovary $(\mathrm{CHO})$ cell lines expressing recombinant $\alpha_{2 A}, \alpha_{2 B}, \alpha_{2 C}$, and $\mathrm{CRF}_{2 \alpha}$, and cell membranes from human embryonal kidney (HEK) 293 expressing recombinant $\mathrm{D}_{2 \mathrm{~A}}$ and $5-\mathrm{HT}_{3}$, were prepared in the Nervous System Department, Novartis Pharma, Basel, Switzerland. They were 
Table 1. Affinity Profile of Iloperidone for Human Receptors

\begin{tabular}{|c|c|c|c|c|}
\hline Receptor & Radioligand & Cell & Internal reference, $\mathrm{K}_{\mathrm{I}}(\mathrm{nM})^{\mathrm{a}}$ & Iloperidone $K_{1}(n M)$ \\
\hline Adenosine $\mathrm{A}_{1}$ & ${ }^{3} \mathrm{H}-\mathrm{DPCPX}$ & $\mathrm{CHO}$ & $\mathrm{CPA}, 5.37$ & $>10,000$ \\
\hline Adenosine $\mathrm{A}_{2 \mathrm{~A}}$ & ${ }^{3} \mathrm{H}-\mathrm{NECA}$ & $\mathrm{CHO}$ & NECA, 93.3 & $>10,000$ \\
\hline Adenosine $\mathrm{A}_{3}$ & ${ }^{125} \mathrm{I}-\mathrm{AB}-\mathrm{MECA}$ & $\mathrm{CHO}$ & NECA, 100 & $>10,000$ \\
\hline$\alpha_{2 \mathrm{~A}}$ adrenoceptor & ${ }^{3} \mathrm{H}-\mathrm{R} X 821002$ & $\mathrm{CHO}$ & $\mathrm{RX} 821002,0.776$ & 162 \\
\hline$\alpha_{2 B}$ adrenoceptor & ${ }^{3} \mathrm{H}-\mathrm{R} X 821002$ & $\mathrm{CHO}$ & $\mathrm{RX} 821002,3.47$ & 162 \\
\hline$\alpha_{2 C}$ adrenoceptor & ${ }^{3} \mathrm{H}-\mathrm{R} X 821002$ & $\mathrm{CHO}$ & RX821002, 3.09 & 16.2 \\
\hline$\beta_{1}$ adrenoceptor & ${ }^{3} \mathrm{H}-\mathrm{CGP} 12177$ & Sf9 & Propanolol, 9.77 & $>10,000$ \\
\hline$\beta_{2}$ adrenoceptor & ${ }^{3} \mathrm{H}-\mathrm{CGP} 12177$ & Sf9 & ICI118551, 3.55 & $>10,000$ \\
\hline Cannabinoid $_{1}$ & ${ }^{3} \mathrm{H}-\mathrm{CP} 55940$ & HEK 293 & WIN55212-2, 708 & $>10,000$ \\
\hline Cholecystokinin $_{\mathrm{A}}$ & ${ }^{3} \mathrm{H}-\mathrm{L}-354,718$ & NIH 3T3 & CCK 8-sulphated, 6030 & $>10,000$ \\
\hline Cholecystokinin $_{B}$ & ${ }^{3} \mathrm{H}-\mathrm{L}-365,260$ & NIH 3T3 & CCK $8,17.8$ & 9333 \\
\hline $\mathrm{CRF}_{2 \alpha}$ & ${ }^{125}$ I-Sauvagine & $\mathrm{CHO}$ & D-Phe CRF, 33.5 & $>10,000$ \\
\hline Dopamine $\mathrm{D}_{2 \mathrm{~A}}$ & ${ }^{3} \mathrm{H}$-Spiperone & HEK 293 & $(+)$ Butaclamol, 8.13 & 21.4 \\
\hline Dopamine transporter & ${ }^{3} \mathrm{H}-\mathrm{WIN} 35428$ & $\mathrm{CHO}-\mathrm{K} 1$ & WIN35428, 25.7 & 2951 \\
\hline $5-\mathrm{HT}_{1 \mathrm{~A}}$ & ${ }^{3} \mathrm{H}-8-\mathrm{OH}$ DPAT & $\mathrm{CHO}-\mathrm{K} 1$ & 8-OH DPAT, 0.692 & 93.1 \\
\hline $5-\mathrm{HT}_{3}$ & ${ }^{3} \mathrm{H}-\mathrm{GR} 65630$ & HEK293 & $5-\mathrm{HT}, 871$ & $>10,000$ \\
\hline $5-\mathrm{HT}_{6}$ & ${ }^{3} \mathrm{H}-\mathrm{LSD}$ & HeLa & Methiothepin, 0.631 & 63.1 \\
\hline $5-\mathrm{HT}_{7}$ & ${ }^{3} \mathrm{H}$-Mesulergine & Sf9 & & 112 \\
\hline Norepinephrine transporter & ${ }^{3} \mathrm{H}-\mathrm{Nis}$ oxetine & MDCK & GBR 12909,813 & 1479 \\
\hline Neurokinin $_{1}$ & ${ }^{3} \mathrm{H}-\mathrm{Sar}^{9} \mathrm{SP}$ & $\mathrm{CHO}$ & Sar'sP, 1.00 & $>10,000$ \\
\hline Neurokinin $_{2}$ & ${ }^{125} \mathrm{I}-\mathrm{NKA}$ & $\mathrm{CHO}$ & $\beta$-Ala NKA, 9.77 & $>10,000$ \\
\hline Neurokinin $_{3}$ & ${ }^{125} \mathrm{I}-\mathrm{NKB}$ & $\mathrm{CHO}$ & Me Phe ${ }^{7}$ KKB, 9.77 & $>10,000$ \\
\hline Opiate $\delta$ & ${ }^{3} \mathrm{H}-\mathrm{DPDPE}$ & $\mathrm{CHO}-\mathrm{K} 1$ & Naloxone, 79.4 & $>10,000$ \\
\hline Opiate $\kappa$ & ${ }^{3} \mathrm{H}-\mathrm{Naloxone}$ & $\mathrm{CHO}-\mathrm{K} 1$ & Naloxone, 0.631 & $>10,000$ \\
\hline Opiate $\mu$ & ${ }^{3} \mathrm{H}-\mathrm{Naloxone}$ & $\mathrm{CHO}-\mathrm{K} 1$ & Naloxone, 0.759 & $>10,000$ \\
\hline Muscarinic $\mathrm{M}_{1}$ & ${ }^{3} \mathrm{H}-\mathrm{N}$-methylscopolamine & $\mathrm{CHO}$ & Atropine, 4.68 & 4898 \\
\hline Muscarinic $\mathrm{M}_{2}$ & ${ }^{3} \mathrm{H}-\mathrm{N}$-methylscopolamine & $\mathrm{CHO}$ & Atropine, 11.0 & 3311 \\
\hline Muscarinic $\mathrm{M}_{3}$ & ${ }^{3} \mathrm{H}-\mathrm{N}$-methylscopolamine & $\mathrm{CHO}$ & Atropine, 10.7 & $>10,000$ \\
\hline Muscarinic $\mathrm{M}_{4}$ & ${ }^{3} \mathrm{H}-\mathrm{N}$-methylscopolamine & $\mathrm{CHO}$ & Atropine, 10.0 & 8318 \\
\hline Muscarinic $\mathrm{M}_{5}$ & ${ }^{3} \mathrm{H}-\mathrm{N}$-methylscopolamine & $\mathrm{CHO}$ & Atropine, 6.31 & $>10,000$ \\
\hline
\end{tabular}

The displacement curves were established with eight concentrations (10-fold dilution steps) of iloperidone. Each concentration was tested in duplicate. The $\mathrm{K}_{\mathrm{I}}$ values are the mean value of three separate experiments. For clarity, SEM-values are omitted since the variation was within $5 \%$ of the mean. ${ }^{a}$ Where an internal reference is given, each assay was performed along with a full dose response curve of an internal reference compound to authenticate the quality.

thawed and homogenized just before the assay. Membranes expressing recombinant $5-\mathrm{HT}_{7}$ (Sf9 cells with baculovirus expression) were prepared by the Biotechnology Dept, Novartis Pharma, Basel, Switzerland.

The following membrane preparations were purchased from NEN Life Science Products, USA: NIH 3T3 cells expressing recombinant $\mathrm{CCK}_{\mathrm{A}}$ and $\mathrm{CCK}_{\mathrm{B}}$; $\mathrm{Sf} 9$ cells expressing recombinant $\beta_{1}$ or $\beta_{2}$ receptors (all baculovirus expression); HeLa cells expressing recombinant 5- $\mathrm{HT}_{6}$ receptors; and $\mathrm{CHO}$ cells expressing recombinant $\mathrm{NK}_{1}, \mathrm{NK}_{2}$, or $\mathrm{NK}_{3}$ receptors. Other membrane preparations were purchased from Receptor Biology Inc: MDCK cells expressing recombinant norepinephrine transporter (hrNET); $\mathrm{CHO}$ cells expressing adenosine $\mathrm{A}_{1}, \mathrm{~A}_{2 \mathrm{~A}}$ or $\mathrm{A}_{3}$ receptors or muscarinic $\mathrm{M}_{1}, \mathrm{M}_{2}, \mathrm{M}_{3}, \mathrm{M}_{4}$ and $\mathrm{M}_{5}$ receptors; HEK 293 cells expressing cannabinoid ${ }_{1}$ receptors; $\mathrm{CHO}-$ $\mathrm{K} 1$ cells expressing recombinant dopamine transporter (hrDAT); and CHO-K1 cells expressing recombinant opiate $\delta$, opiate $\mu$ and opiate $\kappa$ receptors. Membranes from $\mathrm{CHO}-\mathrm{K} 1$ cells expressing recombinant $5-\mathrm{HT}_{1 \mathrm{~A}}$ receptors were obtained from EuroScreen, SA.

\section{Radioligand Binding Assays}

96-well Microtiter Plate Filtration Assay. In general, the membrane preparations were homogenized after thawing and pretreated as required.

Individual radioligand binding assays for different receptors were performed as outlined by Herz et al. (1997) and references therein, with minor modifications if required. The binding studies were performed in 96well plates (Falcon) in a total volume of $250 \mu \mathrm{L}$, consisting of the radioligand, drug (iloperidone or reference compound) and membrane preparation (cells, rat or guinea pig brain membranes) diluted in appropriate buffer. Non-specific binding was determined in the presence of an appropriate drug specific for the receptor under study. The plates were incubated at equilibrium for a specified time, as determined by kinetic experiments, for each receptor assay. Reactions were terminated by flash filtration and inverse transfer to 96well filter plates (96-well cell harvester, filter plates GFC, coated with PAI as necessary, Canberra Packard). The plates were dried for 30 minutes at $56^{\circ} \mathrm{C}$ and sealed 
Table 2. Affinity Profile of Iloperidone for Receptors for Which Human Homologue Was Unavailable

\begin{tabular}{|c|c|c|c|c|}
\hline Receptor, species & Radioligand & Tissue & Internal reference, $K_{I}(n M)^{a}$ & Iloperidone $K_{I}(n M)$ \\
\hline Nicotine, rat & ${ }^{125}$ I-epibatidine & Brain & Epibatidine, 0.1 & $>10,000$ \\
\hline Benzodiazepine, rat & ${ }^{3} \mathrm{H}$-Flunitrazepam & Brain & Diazepam, 4.67 & 12,882 \\
\hline Histamine $\mathrm{H}_{1}$, guinea pig & ${ }^{3} \mathrm{H}$-Pyrilamine & Brain & Pyrilamine, 5.01 & 437 \\
\hline $5-\mathrm{HT}_{1 \mathrm{~B} / 1 \mathrm{D}}$, bovine & ${ }^{125} \mathrm{I}-\mathrm{GTI}$ & Calf caudate & & 89.1 \\
\hline
\end{tabular}

The displacement curves were established with eight concentrations (10-fold dilution steps) of iloperidone. Each concentration was tested in duplicate. The $\mathrm{K}_{\mathrm{I}}$ values are the mean value of three separate experiments. For clarity, SEM-values are omitted since the variation was within $5 \%$ of the mean. ${ }^{a}$ Where an internal reference is given, each assay was performed along with a full dose response curve of an internal reference compound to authenticate the quality.

at the bottom with an adhesive sheet (Topseal, Canberra Packard). Subsequently, $50 \mu \mathrm{L}$ of scintillation fluid (Microscint-20, Canberra Packard) was added to each well, the plates sealed on top and the radioactivity counted in a 96-well plate counter (Topcount, Canberra Packard). The displacement curves were established with eight concentrations (10-fold dilution steps) of iloperidone. Each concentration was tested in duplicate. The $K_{I}$ values are the mean value of three separate experiments.

\section{Additional Binding Studies}

Additional binding studies were performed in accordance with previously described methods: $5-\mathrm{HT}_{1 \mathrm{~B} / 1 \mathrm{D}}$ and 5- $\mathrm{HT}_{7}$ (Bruinvels et al. 1992; Hoyer et al. 1997). Non-specific binding was determined in the presence of $10 \mu \mathrm{M}$ 5-HT (5-HT 1 and 5- $\mathrm{HT}_{7}$ sites).

\section{Data Analysis}

A standard data reduction algorithm was used to calculate percent specific binding in the presence of the test compound as follows:

$$
([\mathrm{B}-\mathrm{NSP}] /[\mathrm{T}-\mathrm{NSP}]) \times 100
$$

where: $\mathrm{B}=$ binding in the presence of test compound, NSP $=$ non-specific binding in the presence of excess inhibitor, and $\mathrm{T}=$ total binding.

$\mathrm{IC}_{50}$ values were derived (where feasible) from a 4-parameter logistic fit and were converted to $\mathrm{K}_{\mathrm{I}}$ values using the Cheng-Prusoff equation (Cheng and Prusoff 1973).

The entire data analysis was performed by a dedicated program linking the raw data to a custom driven Excel 7.0 macro and Graphpad Prism V 2.1. All affinities are expressed as $\mathrm{K}_{\mathrm{I}}$ values $(\mathrm{mol} / \mathrm{L})$.

\section{RESULTS}

The derived in vitro receptor binding profile of iloperidone is included in Table 1 and Table 2. Iloperidone displayed moderate affinity $\left(\mathrm{K}_{\mathrm{I}} 10-100 \mathrm{nM}\right)$ at human $\alpha_{2 \mathrm{C}}$ adrenoceptors $(16.2 \mathrm{nM})$, human $\mathrm{D}_{2 \mathrm{~A}}(21.4 \mathrm{nM})$, human 5- $\mathrm{HT}_{1 \mathrm{~A}}(93.1 \mathrm{nM})$, bovine $5-\mathrm{HT}_{1 \mathrm{~B} / 1 \mathrm{D}}(89.1 \mathrm{nM})$ and human 5- $\mathrm{HT}_{6}$ receptors $(63.1 \mathrm{nM})$. Low affinity $\left(\mathrm{K}_{\mathrm{I}} 100-\right.$ $1000 \mathrm{nM}$ ) was observed at the human $\alpha_{2 \mathrm{~A}}$ adrenoceptor $(162 \mathrm{nM})$, human $\alpha_{2 \mathrm{~B}}$ adrenoceptor $(162 \mathrm{nM})$, guinea pig histamine $\mathrm{H}_{1}(437 \mathrm{nM})$ and human $5-\mathrm{HT}_{7}$ receptors (112 $\mathrm{nM})$. In addition, iloperidone had very low affinity $\left(\mathrm{K}_{\mathrm{I}}\right.$ $1000-10,000 \mathrm{nM})$ at the human $\mathrm{CCK}_{\mathrm{B}}$ receptor, human dopamine and norepinephrine transporters, and human muscarinic $\mathrm{M}_{1}, \mathrm{M}_{2}, \mathrm{M}_{4}$ receptors. There was no significant cross-reactivity $\left(\mathrm{K}_{\mathrm{I}}>10 \mu \mathrm{M}\right)$ at all other receptors tested.

\section{DISCUSSION}

The affinity of iloperidone for a number of receptor sites considered important for antipsychotic activity has been reported previously (Szewczak et al. 1995; Kongsamut et al. 1996). The highest affinity was observed for the rat $\alpha_{1}$-adrenoceptor $\left(\mathrm{K}_{\mathrm{I}} 0.4 \mathrm{nM}\right.$; Szewczak et al. 1995), while the compound also displayed a high affinity $\left(\mathrm{K}_{\mathrm{I}}\right.$ values below $\left.10 \mathrm{nM}\right)$ at the human recombinant 5- $\mathrm{HT}_{2 \mathrm{~A}}$ receptor $\left(\mathrm{K}_{\mathrm{I}} 5.6 \mathrm{nM}\right)$, the short splice form (2B) of the human recombinant $\mathrm{D}_{2}$ receptor $\left(\mathrm{K}_{\mathrm{I}} 6.3 \mathrm{nM}\right)$, and the $\mathrm{D}_{3}$ receptor $\left(\mathrm{K}_{\mathrm{I}} 7.1 \mathrm{nM}\right.$; Kongsamut et al. 1996). These authors reported a $K_{I}$ value of iloperidone for the long splice form of the human $\mathrm{D}_{2}$ receptor of $13.3 \mathrm{nM}$, which is in good agreement with data obtained in the present study $(21.4 \mathrm{nM})$. In addition, Kongsamut et al. (1996) reported a low affinity of iloperidone to receptors of the $\mathrm{D}_{1}$ family: $\mathrm{D}_{1}\left(\mathrm{~K}_{\mathrm{I}} 216 \mathrm{nM}\right)$ and $\mathrm{D}_{5}\left(\mathrm{~K}_{\mathrm{I}} 319 \mathrm{nM}\right)$. The affinity for the $5-\mathrm{HT}_{2 \mathrm{C}}$ receptor was reported as $42.8 \mathrm{nM}$.

The present study extends the radioligand binding profile of iloperidone with a large series of human receptors. A moderate affinity $\left(\mathrm{K}_{\mathrm{I}}\right.$ values between 10 and $100 \mathrm{nM})$ was observed for $\alpha_{2 \mathrm{C}}\left(\mathrm{K}_{\mathrm{I}} 16.2 \mathrm{nM}\right), 5-\mathrm{HT}_{1 \mathrm{~A}}(93.1$ $\mathrm{nM})$ and $5-\mathrm{HT}_{6}(63.1 \mathrm{nM})$ receptors and bovine $5-\mathrm{HT}_{1 \mathrm{~B} / 1 \mathrm{D}}$ receptors $(89.1 \mathrm{nM})$. Since antipsychotic compounds are dosed until a significant occupation $(50-80 \%)$ of $\mathrm{D}_{2}$ receptors is obtained (Nordström et al. 1993; Kapur et al. 2000), one can assume that therapeutic doses of iloperidone will result in relevant occupancy of $\mathrm{D}_{3}$, $5-\mathrm{HT}_{2 \mathrm{~A}}, 5-\mathrm{HT}_{2 \mathrm{C}}, \alpha_{1}$ and $\alpha_{2 \mathrm{C}}$ receptors. Whether 5- $\mathrm{HT}_{1 \mathrm{~A}}$, 


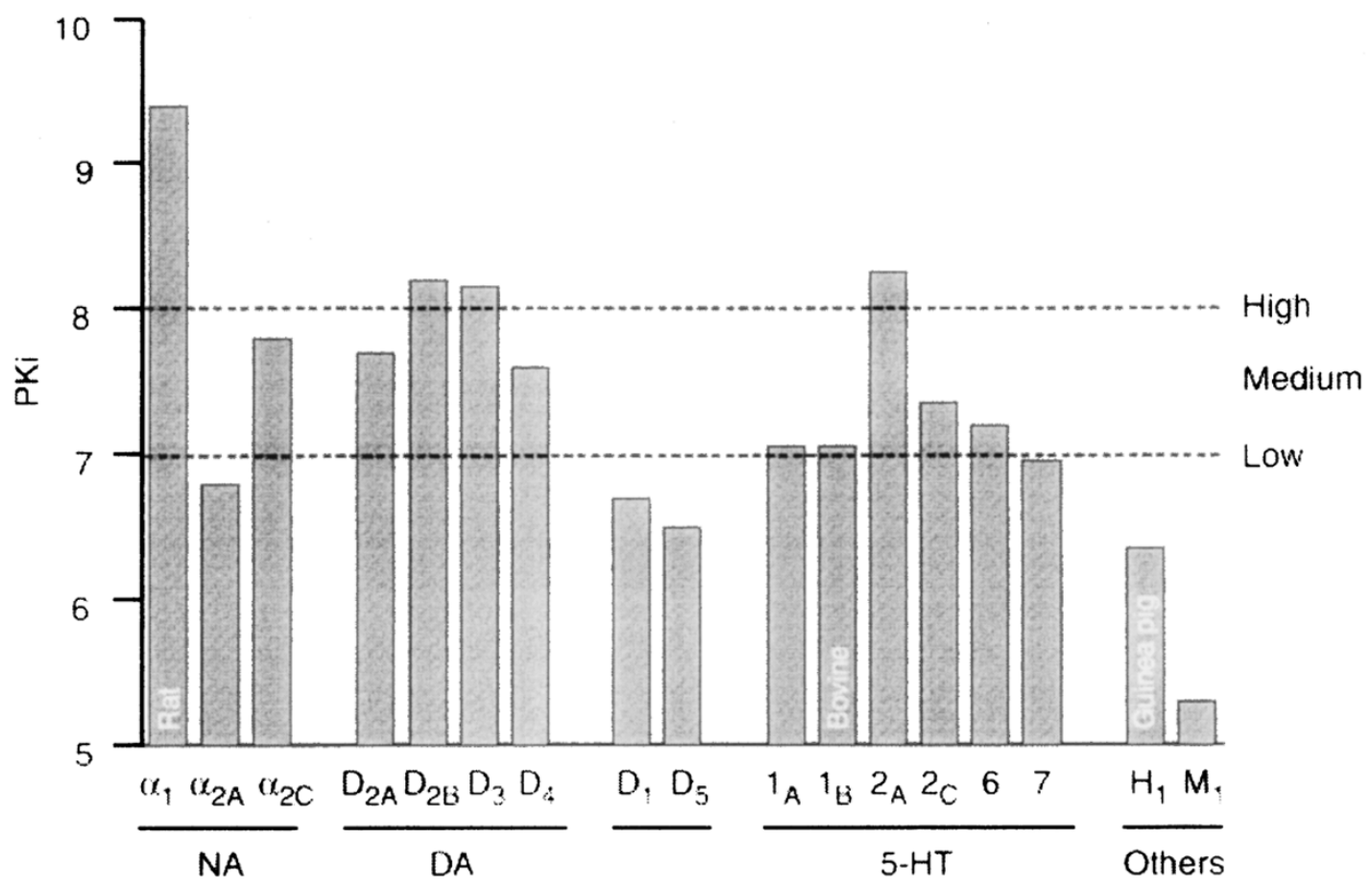

Figure 2. Bargraph of selected receptor affinities $\left(\mathrm{pK}_{\mathrm{I}}\right.$ in $\left.\mathrm{nM}\right)$ of iloperidone. These affinities were measured at recombinant human receptors, with the exception of the $\alpha_{1}$-adrenoceptor (rat), the 5- $\mathrm{HT}_{1 \mathrm{~B}}$ receptor (bovine) and histamine $\mathrm{H}_{1}$ receptor (guinea pig). The displacement curves were established with eight concentrations of iloperidone. Each concentration was tested three times. Variation was within $5 \%$ of the mean. Data for the $\alpha_{1}$, the dopamine receptors, $5-\mathrm{HT}_{2 \mathrm{~A}}$ and 5-HT $2 \mathrm{C}$ receptor were reported previously (Kongsamut et al. 1996).

5- $\mathrm{HT}_{1 \mathrm{~B}}$ and $5-\mathrm{HT}_{6}$ receptors will be occupied is less certain. At therapeutic doses, in vivo binding of iloperidone at receptors with lesser affinity (e.g. the adenosine family of receptors) would be negligible. The binding profile is summarized in graphical form in Figure 2. On the basis of this receptor binding profile one may predict some of iloperidone's clinical properties.

\section{Overall Receptor Binding Affinity}

Considering the present results in conjunction with those reported by Kongsamut et al. (1996), it is evident that iloperidone binds to three classes of monoamine receptor subtypes: dopamine, serotonin and norepinephrine receptors, but not to any other neurotransmitter receptor class. The moderate to high affinity of iloperidone for human $\mathrm{D}_{2}, 5-\mathrm{HT}_{2 \mathrm{~A}}$ and $\alpha_{1}$ receptors suggest that iloperidone will have antipsychotic activity (Baldessarini et al. 1992; Willner 1997). Iloperidone's binding to $5-\mathrm{HT}_{2 \mathrm{C}}$ and $\alpha_{2 \mathrm{C}}$ receptors will modify the therapeutic response and perhaps add additional therapeutic activity. On the other hand, iloperidone is devoid of affinity for receptor sites which are related to side effects (e.g. muscarine and histamine $\mathrm{H}_{1}$ receptors).
The potential relevance of each individual receptor site is discussed, roughly in order of declining affinity.

\section{Affinity for $\alpha_{1}$ Receptors}

Three different subtypes of the human $\alpha_{1}$-adrenoceptor $\left(\alpha_{1 \mathrm{~A}}, \alpha_{1 \mathrm{~B}}, \alpha_{1 \mathrm{D}}\right)$ have been identified by molecular cloning (Bylund 1992). The affinity of iloperidone to those $\alpha_{1}$ adrenoceptor subtypes is not yet known. But since iloperidone displayed a very high affinity for rat brain $\alpha_{1}$ adrenoceptors, it probably will have significant affinity for the human $\alpha_{1 \mathrm{~A}}, \alpha_{1 \mathrm{~B}}$ and $\alpha_{1 \mathrm{D}}$ subtypes. Animal experiments provide circumstantial evidence that $\alpha_{1}$ blockade might contribute to antipsychotic activity. For instance, prazosin administration to rats dose-dependently decreased burst firing and regularized the firing pattern of ventral tegmental dopamine neurons (Grenhoff and Svensson 1993). Disruption of prepulse inhibition by the psychotomimetic drug, phencyclidine, in rats (a putative model for the sensory motor gating deficit of schizophrenic patients), is normalized by $\alpha_{1}$-adrenoceptor blocking antipsychotic compounds (Bakshi and Geyer 1997). These two preclinical experiments suggest that inappropriate $\alpha_{1}$-adrenoceptor stimulation could 
be involved in the pathogenesis of schizophrenia and $\alpha_{1}$-adrenoceptor blockade could thus be a useful pharmacologic attribute for an antipsychotic compound. There are however, side effects such as postural hypotension that can occur through $\alpha_{1}$-adrenergic blockade. Clinical studies have shown that clozapine frequently causes postural hypotension early in the course of treatment (Baldessarini and Frankenburg 1991). Iloperidone has shown similar effects early in treatment but tolerance is seen to develop as treatment continues (data on file).

\section{Affinity for 5- $\mathrm{HT}_{2 \mathrm{~A}}$ Receptors}

As indicated in the introductory section, iloperidone adheres to the theory put forward by Meltzer et al. (1989), in that it has a higher affinity for the $5-\mathrm{HT}_{2 \mathrm{~A}}$ receptor than for the $\mathrm{D}_{2}$ receptor. The theory predicts a better tolerability than classical antipsychotic compounds. Interestingly, the hallucinogen psilocybin induced schizophrenia-like psychosis in humans which was blocked by the selective $5-\mathrm{HT}_{2 \mathrm{~A}}$ receptor antagonist, ketanserin (Vollenweider et al. 1998). Effective doses of psilocybin significantly decreased $\left[{ }^{11} \mathrm{C}\right]$ raclopride binding in the striatum, which is indicative for an increase in endogenous dopamine levels in this brain structure (Vollenweider et al. 1999). Unexpected though, selective $5-\mathrm{HT}_{2 \mathrm{~A}}$ receptor antagonists were not very effective in the treatment of psychoses in schizophrenia (Truffinet et al. 1999; Hoechst Marion Roussel, Company Press Release, 1999). Nevertheless, if combined with $\mathrm{D}_{2}$ receptor blockade, $5-\mathrm{HT}_{2 \mathrm{~A}}$ blockade might still represent a useful pharmacologic principle.

Morisset et al. (1999) have proposed that central $5-\mathrm{HT}_{2 \mathrm{~A}}$ receptor blockade could represent a mechanism for improved cognition. The authors showed that antipsychotics with high 5- $\mathrm{HT}_{2 \mathrm{~A}}$ receptor antagonist affinity, including iloperidone, stimulated histamine neuron activity, which enhances alertness via $\mathrm{H}_{1}$ receptor activation.

\section{Affinity for $D_{2 A}, D_{2 B}, D_{3}$ and $D_{4}$ Receptors}

According to their different pharmacologic profile and intracellular signaling pathways, dopamine receptors have traditionally been classified into two major populations, designated $\mathrm{D}_{1}$ and $\mathrm{D}_{2}$. Molecular cloning techniques have identified additional subtypes of dopamine receptor whose profiles suggest them to be members of either the $D_{1}$ or $D_{2}$ families (Sokoloff and Schwartz 1995). Thus, the cloned $D_{5}$ receptor resembles the classical $D_{1}$ receptor in being positively coupled to cAMP production and also in terms of sequence homology and the absence of introns. On the other hand, the $\mathrm{D}_{3}$ and $\mathrm{D}_{4}$ subtypes most closely resemble the $\mathrm{D}_{2}$ receptor in being inhibitory on cAMP production and having a similar intron distribution (Sokoloff and Schwartz
1995). Alternative splicing of the $D_{2}$ receptor produces a long $\left(D_{2 A}\right)$ and a short $\left(D_{2 B}\right)$ variant in humans (reviewed by Sokoloff and Schwartz 1995). The $\mathrm{D}_{2}$ family of receptors has been strongly linked to both the beneficial and side effects associated with antipsychotic agents. Attempts to divorce therapeutic benefit from adverse effects were given great impetus by reports that clozapine bound with high affinity and some selectivity to the dopamine $\mathrm{D}_{4}$ over $\mathrm{D}_{2}$ receptor subtypes (Van Tol et al. 1991). High affinity antagonists with marked selectivity have now been synthesized and, in some cases, examined in schizophrenic patients. No therapeutic efficacy was apparent (Kramer et al. 1997; Truffinet et al. 1999). These results indicate that $\mathrm{D}_{4}$ receptor blockade is unlikely to be a major contributor to antipsychotic activity. Although iloperidone displayed relevant affinity for the human $D_{4}$ receptor $\left(K_{I} 25 \mathrm{nM}\right.$; Kongsamut et al. 1996), this probably has no therapeutic consequence.

Iloperidone, like most commonly used antipsychotics, has significant affinity for the dopamine $\mathrm{D}_{3}$ receptor and is likely to interact at these sites at therapeutically relevant doses. Selective $D_{3}$ receptor antagonists have been described, but these are not yet tested in schizophrenic patients. Based on the pattern of expression of the $D_{3}$ receptor, this subtype could, however, be relevant for antipsychotic activity. The $\mathrm{D}_{3}$ receptor is mainly expressed in mesocorticolimbic projection areas such as the medial forebrain bundle, the shell of the nucleus accumbens, olfactory tubercle, amygdala and cortical structures, but less in the nigrostriatal and tuberoinfundibular dopamine systems (Bouthenet et al. 1991).

Finally, differences in affinity for the two splice forms of the human $D_{2}$ receptor have also attracted attention (Malmberg et al. 1993; Usiello et al. 2000). Whereas most antipsychotic compounds display equal affinity for both variants, clozapine and remoxipride, two compounds with a low propensity to cause EPS, bound with higher affinity to the $\mathrm{D}_{2 \mathrm{~B}}$ than to the $\mathrm{D}_{2 \mathrm{~A}}$ form of the receptor. Usiello et al. (2000) found that the cataleptic effect of the typical antipsychotic haloperidol was absent in $\mathrm{D}_{2 \mathrm{~A}}$ receptor deficient mice. These authors suggested that therapeutic activity could be related to blockade of presynaptic $\mathrm{D}_{2 \mathrm{~B}}$ receptors, whereas extrapyramidal side effects could be avoided if the compound would fail to bind to $\mathrm{D}_{2 \mathrm{~A}}$ receptors. As published by Kongsamut et al. (1996), iloperidone displays higher affinity for the $D_{2 B}$ than for the $D_{2 A}$ form which, according to the foregoing, would indicate a reduced propensity to cause EPS.

\section{Affinity for $\alpha_{2 \mathrm{~A}}$ and $\alpha_{2 \mathrm{C}}$ Adrenoceptors}

Iloperidone's next highest affinity is to the norepinephrine $\alpha_{2 C}$ binding site. Clozapine displays nanomolar affinity for the $\alpha_{2 C}$ adrenoceptor $\left(\mathrm{K}_{\mathrm{I}} 9.1 \mathrm{nM}\right)$ and some se- 
lectivity relative to the $\alpha_{2 \mathrm{~A}}$ subtype $\left(\mathrm{K}_{\mathrm{I}} 50 \mathrm{nM}\right)$ (Schotte et al. 1996). It has been speculated that clozapine's superior therapeutic activity is at least partly explained by $\alpha_{2}$-adrenoceptor blockade (Nutt 1994; Litman et al. 1996; Hertel et al. 1999). Other therapeutic effects of clozapine may also be related to $\alpha_{2}$-adrenoceptor blockade. In monkeys with MPTP-induced Parkinsonism, dyskinetic movements induced by L-dopa were diminished by idazoxan, an $\alpha_{2}$ antagonist (Henry et al. 1999; Grondin et al. 2000). Thus, blockade of $\alpha_{2}$-adrenergic receptors could explain the potent antidyskinetic effect of clozapine (Bennett et al. 1994; Pierelli et al. 1998). Experiments in genetically altered mice show that overexpression of $\alpha_{2 C}$ receptors contributes to behavioral despair and accordingly, blockade of $\alpha_{2 C}$ receptors could be antidepressive (Sallinen et al. 1999). Other preclinical studies indicate that overexpression of $\alpha_{2 C}$ receptors worsens spatial recognition and induces anxiety-like behavior (Björklund et al. 1998, 1999). These effect were reverted by an $\alpha_{2}$ antagonist, suggesting that blockade of $\alpha_{2 C}$ receptors might result in improved cognition and anxiolytic activity. On the other hand, also undesired properties may be related to blockade of $\alpha_{2}$-adrenoceptors. Idazoxan and other $\alpha_{2}$ antagonists are proconvulsant in mice (Jackson et al. 1991). Such an effect was not seen in a mutant mice strain that lacked functional $\alpha_{2 \mathrm{~A}}$ receptors (Janumpalli et al. 1998), suggesting that proconvulsant activity is related to blockade of $\alpha_{2 \mathrm{~A}}$ adrenergic receptors.

Iloperidone has a low affinity for $\alpha_{2 \mathrm{~A}}$ receptors indicating a low propensity to induce convulsions. In contrast, the affinity of iloperidone for $\alpha_{2 C}$-adrenoceptors could be of clinical relevance as it might result in antidepressant and anxiolytic activity and in improved cognition.

\section{Affinity for 5-HT $2 \mathrm{C}$ Receptors}

Recent research has shown that the $5-\mathrm{HT}_{2 \mathrm{C}}$ antagonist, SB206,553 dose-dependently increased the firing rate of VTA and locus coeruleus (LC) adrenergic neurons in rats (Gobert et al. 2000). These authors also reported that the $5-\mathrm{HT}_{2 \mathrm{C}}$ antagonist dose-dependently increase levels of dopamine (DA) and noradrenaline (NA) but not serotonin in the frontal cortex. Clozapine has been shown to preferentially increase dopamine release in the medial prefrontal cortex (Moghaddam and Bunney 1990). Since clozapine is a potent $5-\mathrm{HT}_{2 \mathrm{C}}$ antagonist (Schotte et al. 1996), the effects of clozapine on dopamine release in the prefrontal cortex might be due, at least partly, to blockade of $5-\mathrm{HT}_{2 \mathrm{C}}$. Dopamine hypofunction in cortical dopamine projection has been suggested to be responsible for negative symptomatology (Davis et al. 1991). Iloperidone shows moderate affinity to the $5-\mathrm{HT}_{2 \mathrm{C}}$ receptors $\left(\mathrm{K}_{\mathrm{I}} 42.8 \mathrm{nM}\right.$; Kongsamut et al. 1996) which might lead to disinhibition of the VTA and
LC neurons, enhanced cortical DA and NA in the frontal cortex and thus an effect against negative symptoms of schizophrenia.

Activation of $5-\mathrm{HT}_{2 \mathrm{C}}$ receptors by fenfluramine or $\mathrm{mCPP}$ suppresses food intake in laboratory animals. For this reason the blockade of $5-\mathrm{HT}_{2 \mathrm{C}}$ receptors is suspected to contribute to the hyperphagia and weight gain observed with antipsychotic treatment. Chronic treatment of rats with selective 5- $\mathrm{HT}_{2 \mathrm{C}}$ receptor antagonists did not lead to weight gain (Kennett et al. 1997). Also the antipsychotic drug ziprasidone displays relevant $5-\mathrm{HT}_{2 \mathrm{C}}$ blockade (Schotte et al. 1996), but did not induce profound weight gain in humans (Allison et al. 1999). Thus, although $5-\mathrm{HT}_{2 \mathrm{C}}$ receptor agonists induce hypophagia, the opposite is not necessarily observed with antagonists. Also iloperidone, despite its affinity for $5-\mathrm{HT}_{2 \mathrm{C}}$ receptors, produced, if compared to placebo, minimal weight gain in schizophrenic patients (data on file).

Selective $5-\mathrm{HT}_{2 \mathrm{C}}$ receptor antagonists displayed anxiolytic activity (Kennett et al. 1996, 1997) and suppressed haloperidol-induced catalepsy (Reavill et al. 1999). On theoretical grounds, $5-\mathrm{HT}_{2 \mathrm{C}}$ receptor antagonists might also be useful for the treatment of Parkinson's disease (Fox and Brotchie 1999). Iloperidone's affinity for 5- $\mathrm{HT}_{2 \mathrm{C}}$ receptors could, therefore help to explain the low propensity to induce catalepsy and the anxiolytic effects seen in animal studies (Corbett et al. 1993).

\section{Affinity for 5- $\mathrm{HT}_{6}$ Receptors}

The relevance of $5-\mathrm{HT}_{6}$ receptor blockade in the pharmacologic profile of antipsychotic compounds remains speculative. Roth et al. (1994) reported that clozapine and several atypical antipsychotic agents (rilapine, olanzapine, tiospirone, fluperlapine, clorotepine and zotepine) had high affinities for the $5-\mathrm{HT}_{6}$ receptor. It is interesting that selective $5-\mathrm{HT}_{6}$ receptor antagonist, Ro 04-6790 in rats increased cholinergic neurotransmission (Bentley et al. 1999). Similarly, clozapine, which has relevant 5- $\mathrm{HT}_{6}$ receptor affinity (Glatt et al. 1995; Schotte et al. 1996), increased extracellular levels of acetylcholine in rat prefrontal cortex (Parada et al. 1997). It is therefore conceivable that clozapine increases extracellular levels of acetylcholine via blockade of $5-\mathrm{HT}_{6}$ receptors. Blockade of 5- $\mathrm{HT}_{6}$ receptors could thus, via increased cholinergic neurotransmission, contribute to improved cognitive function. The present results show that iloperidone has moderate affinity for $5-\mathrm{HT}_{6}$ receptors, while the affinity for muscarine receptors is low. These two features in combination suggest that iloperidone could display efficacy against neurocognitive deficits in patients with schizophrenia. However, it is not certain whether therapeutic doses of iloperidone will be high enough to obtain significant occupancy of the $5-\mathrm{HT}_{6}$ receptor, as its affinity measured in the present experiments is rather moderate $\left(\mathrm{K}_{\mathrm{I}} 63.1 \mathrm{nM}\right)$. 


\section{Affinity for 5-HT ${ }_{1 \mathrm{~A}}$ Receptors}

The same argument holds for the $5-\mathrm{HT}_{1 \mathrm{~A}}$ receptor since the affinity of iloperidone for human $5-\mathrm{HT}_{1 \mathrm{~A}}$ receptors amounted to $93.1 \mathrm{nM}$, only. In a cellular assay, iloperidone produced a concentration-dependent surmountable antagonism against the $5-\mathrm{HT}_{1 \mathrm{~A}}$ receptor agonist, 8-OH-DPAT (mean [S.E.M.] $\mathrm{pK}_{\mathrm{B}} 7.69$ [0.18]; data on file).

Post-mortem studies of patients with schizophrenia have revealed increased numbers of $5-\mathrm{HT}_{1 \mathrm{~A}}$ receptors in the prefrontal cortex (Hashimoto et al. 1993; Burnet et al. 1997). Intrinsic activation of these receptors hyperpolarizes the neurons and reduces the output of their neurotransmitter glutamate. Loss and/or hypoactivity of cortical glutamatergic neurons has been postulated to underlie the cognitive impairment in Alzheimer's disease (Francis et al. 1993). Therefore, the normalization of glutamate output by a $5-\mathrm{HT}_{1 \mathrm{~A}}$ antagonist such as iloperidone might help to ameliorate cognitive impairment in patients with schizophrenia.

\section{Affinity for Muscarinic Receptors}

The low or negligible affinity of iloperidone for muscarinic receptors indicates that it may have a low propensity to cause side effects such as dry mouth, blurred vision, increased frequency of micturition or other anticholinergic effects.

\section{Affinity for Histamine $\mathrm{H}_{1}$ Receptors}

It is remarkable that antipsychotic drugs with high affinity for histamine $\mathrm{H}_{1}$ receptors, like clozapine, olanzapine or thioridazine cause profound increases in body weight, whereas compounds with smaller $\mathrm{H}_{1}$ affinity are less active in this respect (Allison et al. 1999). Also other compounds with high $\mathrm{H}_{1}$ receptor affinity like the antidepressant mirtazapine (Fawcett and Barkin 1998), the antihypertensive ketanserin (Brogden and Sorkin 1990), or the migraine prophylactic pizotifen (Cleland et al. 1997) induce significant weight gain. These clinical observations are supplemented by preclinical studies showing that application of $\mathrm{H}_{1}$ receptor antagonists or depletion of histamine elicits a feeding response (Doi et al. 1994). Iloperidone displays low affinity for the histamine $\mathrm{H}_{1}$ receptor and indeed has shown little effect on body weight of schizophrenic patients (data on file).

\section{Affinity for Other Receptors}

The affinity of iloperidone for other receptors such as the $5 \mathrm{HT}_{3}$ and nicotine cholinergic receptors is less than $10 \mu \mathrm{M}\left(\mathrm{pK}_{\mathrm{I}}<5.0\right)$, indicating that iloperidone is inactive at these sites.

\section{CONCLUSION}

Iloperidone is characterized by a broad spectrum of dopamine, norepinephrine and serotonin antagonism. Thus, as with other new antipsychotics, iloperidone has a high affinity for $5-\mathrm{HT}_{2 \mathrm{~A}}$ receptors and $\alpha_{1}$ adrenergic receptors and moderate affinity for $\mathrm{D}_{2}$ receptors, indicating antipsychotic efficacy, with a reduced propensity to induce EPS. Favourable properties are also suggested by its additional receptor profile. The moderate $\mathrm{D}_{2}$ receptor affinity is balanced by comparable affinity for $\alpha_{2 \mathrm{C}}$ adrenoceptors, and $5-\mathrm{HT}_{2 \mathrm{C}}$, suggesting potential improvements in cognition and negative symptoms. Moreover, blockade of $\alpha_{2 C}$ adrenoceptors might translate into antidepressant and anxiolytic activity. Low affinity for histamine $\mathrm{H}_{1}$ receptors suggests that iloperidone has limited propensity to induce weight gain. Extremely low activity at cholinergic receptors suggests that side effects associated with anticholinergic agents such as dry mouth, blurred vision and increased frequency of micturition will be avoided. Due to the low affinity of iloperidone for $\alpha_{2 \mathrm{~A}}$ receptors proconvulsive activity is not expected.

This broad receptor binding profile indicates that iloperidone has the potential to be an effective and welltolerated agent in the treatment of psychotic disorders. Indeed, preliminary studies have confirmed the favourable efficacy and tolerability of iloperidone in patients with schizophrenia (Davidson et al. 1994; Borison et al. 1996; Cutler et al. 1996).

\section{ACKNOWLEDGMENTS}

Hans Kalkman, Natarajan Subramanian and Daniel Hoyer are employees of Novartis Pharma AG.

\section{REFERENCES}

Allison DB, Mentore JL, Heo M, Chandler LP, Cappelleri JC, Infante MC, Weiden PJ (1999): Antipsychotic-induced weight gain: a comprehensive research synthesis. Am J Psychiatry 156:1686-1696

Bakshi VP, Geyer MA (1997): Phencyclidine-induced deficits in prepulse inhibition are blocked by prazosin, an $\alpha-1$ noradrenergic antagonist. J Pharmacol Exp Ther 283: 666-674

Baldessarini RJ, Frankenburg R (1991): Clozapine-a novel antipsychotic agent. N Eng J Med 324:746-754

Baldessarini RJ, Huston-Lyons D, Campbell A, Marsh E, Cohen BM (1992): Do central antiadrenergic actions contribute to the atypical properties of clozapine? Br J Psychiatry Suppl 17:12-16

Bennett JP, Landow ER, Dietrich S, Schuh LA (1994): Suppression of dyskinesias in advanced Parkinson's disease: moderate daily clozapine doses provide long-term dyskinesia reduction. Mov Disord 9:409-414 
Bentley JC, Bourson A, Boess FG, Fone KCF, Marsden CA, Petit N, Sleight AJ (1999): Investigation of stretching behaviour induced by the selective $5-\mathrm{HT}_{6}$ receptor antagonist, Ro 04-6790, in rats. Br J Pharmacol 126:15371542

Björklund M, Sirviö J, Puoliväli J, Sallinen J, Jäkälä P, Scheinin M, Kobilka BK, Riekkinen P (1998): $\alpha 2$ C-Adrenoceptoroverexpressing mice are impaired in executing nonspatial and spatial escape. Mol Pharmacol 54:569-576

Björklund M, Sirviö J, Sallinen J, Scheinin M, Kobilka BK, Riekkinen P (1999): Alpha2C-adrenoceptor overexpression disrupts execution of spatial and non-spatial search patterns. Neurosci 88:1187-1198

Borison RL, Huff FJ, Griffiths L, Ramaswamy R, Shipley JE (1996): Efficacy of $4 \mathrm{mg} /$ day and $8 \mathrm{mg}$ /day iloperidone (HP 873) administered to schizophrenic patients for 42 days. Psychopharmacol Bull 32:416 (abstr)

Bouthenet M-L, Souil E, Martres MP, Sokoloff P, Giros B, Schwartz JC (1991): Localization of dopamine $\mathrm{D}_{3}$ receptor mRNA in the rat brain using in situ hybridization histochemistry: comparison with dopamine $\mathrm{D}_{2}$ receptor mRNA. Brain Res 564:203-219

Brogden RN, Sorkin EM (1990): Ketanserin. A review of its pharmacodynamic and pharmacokinetic properties, and therapeutic potential in hypertension and peripheral vascular diesease. Drugs 40:903-949

Bruinvels AT, Lery H, Nozulak J, Palacios JM, Hoyer D (1992): 5-HT $\mathrm{HD}_{1 \mathrm{D}}$ binding sites in various species: similar pharmacological profile in dog, monkey, calf, guineapig and human brain membranes. Naunyn Schmiedeberg's Arch Pharmacol 346:243-248

Burnet PWJ, Eastwood SL, Harrison PJ (1997): [ $\left.{ }^{3} \mathrm{H}\right]$ WAY100635 for $5-\mathrm{HT}_{1 \mathrm{~A}}$ receptor autoradiography in human brain: a comparison with $\left[{ }^{3} \mathrm{H}\right] 8-\mathrm{OH}-\mathrm{DPAT}$ and demonstration of increased binding in the frontal cortex in schizophrenia. Neurochem Int 30:565-574

Bylund DB (1992): Subtypes of $\alpha_{1}$ - and $\alpha_{2}$-adrenergic receptors. FASEB J 6:832-839

Cheng Y, Prusoff WH (1973): Relationship between the inhibition constant $\left(\mathrm{K}_{\mathrm{I}}\right)$ and the concentration of inhibitor which causes 50 per cent inhibition $\left(\mathrm{IC}_{50}\right)$ of an enzymatic reaction. Biochem Pharmacol 22:3099-3108

Cleland PG, Barnes D, Elrington GM, Loizou LA, Rawes GD (1997): Studies to assess if pizotifen improves migraine beyond the benefit offered by acute sumatriptan alone. Eur Neurol 38:31-38

Conley RR, Tamminga CA, Kelly DL, Richardson CM (1999): Treatment-resistant schizophrenic patients respond to clozapine after olanzapine non-response. Biol Psychiatry 46:73-77

Corbett R, Hartman H, Kerman LL, Woods AT, Strupczewski GC, Helsey GC, Conway PC, Dunn RW (1993): Effects of atypical antipsychotic agents on social behavior in rodents. Pharmacol Biochem Behav 45:9-17

Creese I, Burt DR, Snyder SH (1976): Dopamine receptor binding predicts clinical and pharmacological potencies of antischizophrenic drugs. Science 192:481-483

Cutler NR, Shipley JE, Varaklis J, Hourani J, Jhee SS, Sramek JJ (1996): A bridging study of iloperidone in schizophrenic inpatients. Psychopharmacol Bull 32:482 (abstr)

Davidson M, Brecher M, Kahn R, Stern R, Macaluso J (1994):
Iloperidone (HP 873): a study of safety and tolerance in schizophrenic inpatients. Psychopharmacol Bull 30:664 (abstr)

Davis KL, Kahn RS, Ko G, Davidson M (1991): Dopamine in schizophrenia: a review and reconceptualization. Am J Psychiatr 148:1474-1486

Doi T, Sakata T, Yoshimatsu H, Machidori H, Kurokawa M, Jayasekara LA, Niki N (1994): Hypothalamic neuronal histamine regulates feeding circadian rhythm in rats. Brain Res 641:311-318

Fawcett J, Barkin RL (1998): Review of the results from clinical studies on the efficacy, safety and tolerability of mirtazapine for the treatment of patients with major depression. J Affect Disord 51:267-285

Fox SH, Brotchie JM (1999): A role for 5-HT2C receptor antagonists in the treatment of Parkinson's disease? Drug News Perspec 12:477-483

Francis PT, Sims NR, Procter AW, Bowen DM (1993): Cortical pyramidal neurone loss may cause glutamatergic hypoactivity and cognitive impairment in Alzheimer's disease: investigative and therapeutic perspectives. J Neurochem 60:1589-1604

Glatt CE, Snowman AM, Sibley DR, Snyder SH (1995): Clozapine: selective labeling of sites resembling $5-\mathrm{HT}_{6}$ serotonin receptors may reflect psychoactive profile. Mol Med 1:398-406

Gobert A, Rivet JM, Lejeune F, Newman-Tancredi A, Adhumeau-Auclair A, Nicolas JP, Cistarelli L, Melon C, Millan MJ (2000): Serotonin (2C) receptors tonically suppress the activity of mesocortical dopaminergic and adrenergic, but not serotonergic, pathways: a combined dialysis and electrophysiological analysis in the rat. Synapse 36(3):205-221

Grenhoff J, Svensson TH (1993): Prazosin modulates firing pattern of dopamine neurons in rat ventral tegmental area. Eur J Pharmacol 233:79-84

Grondin R, Tahar AH, Doan VD, Ladure P, Bédard PJ (2000): Adrenoceptor antagonism with idazoxan improves L-dopa-induced dyskinesias in MPTP monkeys. Naunyn Schmiedeberg's Arch Pharmacol 361:181-186

Hashimoto T, Kitamura N, Kajimoto Y, Shiria Y, Shirakawa O, Mita T, Nishino N, Tanaka C (1993): Differential changes in serotonin $5-\mathrm{HT}_{1 \mathrm{~A}}$ and $5-\mathrm{HT}_{2}$ receptor binding in patients with chronic schizophrenia. Psychopharmacology 112:S35-S39

Henry B, Fox SH, Peggs D, Crossman AR, Brotchie JM (1999): The $\alpha_{2}$-Adrenergic receptor antagonist idazoxan reduces dyskinesia and enhances anti-Parkinson actions of L-Dopa in the MPTP-lesioned primate model of Parkinson's disease. Mov Disord 14:744-753

Hertel P, Fagerquist MV, Svensson TH (1999): Enhanced cortical dopamine output and antipsychotic-like effects of raclopride by $\alpha_{2}$ adrenoceptor blockade. Science 286: 2020-2022

Herz JM, Thomsen WJ, Yarbrough GG (1997): Molecular approaches to receptors as targets for drug discovery. J Recept Signal Transduct Res 17:671-776

Hoechst Marion Roussel announces management decisions on priority pipeline products. Company Press Release, July 221999

Hoyer D, Kleuser B, Sutcliffe JG (1997): Pharmacological 
profile of human 5-Hydroxytryptamine $5-\mathrm{HT}_{7}$ receptors expressed in insect cells using the baculovirus system. Br J Pharmacol 120:119P

Jackson HC, Dickinson SL, Nutt DJ (1991): Exploring the pharmacology of the proconvulsant effects of $\alpha_{2}$ adrenoceptor antagonists in mice. Psychopharmacol 105:558-562

Janumpalli S, Butler LS, MacMillan LB, Limbird LE, McNamara JO (1998): A point mutation (D79N) of the alpha2A adrenergic receptor abolishes the antiepileptogenic action of endogenous norepinephrine. J Neurosci 18:2004-2008

Kapur S, Zipursky R, Jones C, Remington G, Houle S (2000): Relationship between dopamine $\mathrm{D}_{2}$ occupancy, clinical response, and side effects: a double-blind PET study of first-episode schizophrenia. Am J Psychiatr 157:514-520

Kennett GA, Wood MD, Bright F, Cilia J, Piper DC, Gager T, Thomas D, Baxter GS, Forbes IT, Ham P, Blackburn TP (1996): In vitro and in vivo profile of SB 206553, a potent $5-\mathrm{HT}_{2 \mathrm{C}} / 5-\mathrm{HT}_{2 \mathrm{~B}}$ receptor antagonist with anxiolytic properties. Br J Pharmacol 117:427-434

Kennett GA, Wood MD, Bright F, Trail B, Riley G, Holland V, Avenell KY, Stean T, Upton N, Bromidge S, Forbes IT, Brown AM, Middlemiss DN, Blackburn TP (1997): SB 242084, a selective and brain penetrant 5- $\mathrm{HT}_{2 \mathrm{C}}$ receptor antagonist. Neuropharmacol 36:609-620

Kongsamut S, Roehr JE, Cai J, Hartman HB, Weissensee P, Kerman LL, Tang L, Sandrasagra A (1996): Iloperidone binding to human and rat dopamine and 5-HT receptors. Eur J Pharmacol 317:417-423

Kramer MS, Last B, Getson A, Reines SA (1997): The effects of a selective D4 dopamine receptor antagonist (L-745, 870) in acutely psychotic inpatients with schizophrenia. Arch Gen Psychiatr 54:567-572

Litman RE, Su TP, Potter WZ, Hong WW, Pickar D (1996): Idazoxan and response to typical neuroleptics in treatment-resistant schizophrenia. Comparison with the atypical neuroleptic, clozapine. Br J Psychiatry 168:571-579

Leucht S, Pitschel-Waltz G, Abraham D, Kissling W (1999): Efficacy and extrapyramidal side-effects of the new antipsychotics olanzapine, quetiapine, risperidone, and sertindole compared to conventional antipsychotics and placebo. A meta-analysis of randomized controlled trials. Schizophr Res 35:51-68

Malmberg Å, Jackson DM, Eriksson A, Mohell N (1993): Unique binding characteristics of antipsychotic agents interacting with human dopamine $\mathrm{D}_{2 \mathrm{~A}}, \mathrm{D}_{2 \mathrm{~B}}$ and $\mathrm{D}_{3}$ receptors. Mol Pharmacol 43:749-754

Meltzer HY, Matsubara S, Lee JC (1989): Classification of typical and atypical antipsychotic drugs on the basis of dopamine D-1, D-2 and serotonin pKi values. J Pharmacol Exp Ther 251:238-246

Moghaddam B, Bunney BS (1990): Acute effects of typical and atypical antipsychotic drugs on the release of dopamine from prefrontal cortex, nucleus accumbens, and striatum of the rat: an in vivo microdialysis study. J Neurochem 54:1755-1760

Morisset S, Sahm UG, Traiffort E, Tardivel-Lacombe J, Arrang JM, Schwartz JC (1999): Atypical neuroleptics enhance histamine turnover in brain via 5 -Hydrox-

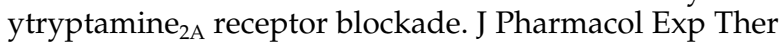
288:590-596
Nordström AL, Farde L, Wiesel FA, Forslund K, Pauli S, Halldin C, Uppfeldt G (1993): Central D2-dopamine receptor occupancy in relation to antipsychotic drug effects: a double blind PET study of schizophrenic patients. Biol Psychiatr 33:227-235

Nutt DJ (1994): Putting the \&lsquo;A\&rsquo; in atypical: does $\alpha_{2}$-adrenoceptor antagonism account for the therapeutic advantage of new antipsychotics? J Psychopharmacol 8:193-195

Parada MA, Hernandez L, Puig de Parada M, Rada P, Murzi E (1997): Selective action of acute systemic clozapine on acetylcholine release in the rat prefrontal cortex by reference to the Nucleus Accumbens and Striatum. J Pharmacol Exp Ther 281:582-588

Pierelli F, Adipietro A, Soldati G, Fattapposta F, Pozzessere G, Scoppetta C (1998): Low dosage clozapine effects on L-dopa induced dyskinesias in parkinsonian patients. Acta Neurol Scand 97:295-299

Reavill C, Kettle A, Holland V, Riley G, Blackburn TP (1999): Attenuation of haloperidol-induced catalepsy by a $5-\mathrm{HT}_{2 \mathrm{C}}$ receptor antagonist. Br J Pharmacol 126: $572-574$

Roth BL, Craigo SC, Choudhary MS, Uluer A, Monsma Jr F, Hen Y, Meltzer H, Sibley D (1994): Binding of typical and atypical antipsychotic agents to 5-hydroxytryptamine-6 and 5-hydroxytryptamine-7 receptors. J Pharmacol Exp Ther 268:1403-1410

Sallinen J, Haapalinna A, MacDonald E, Viitamaa T, Lähdesmäki J, Rybnikova E, Pelto-Huikko M, Kobilka BK, Scheinin M (1999): Genetic alteration of the $\alpha_{2}$-adrenoceptor subtype $\mathrm{C}$ in mice affects the development of behavioral despair and stress-induced increase in plasma corticosterone levels. Mol Psychiatry 4:443-452

Schotte A, Janssen PFM, Gommeren W, Luyten WHML, van Gompel P, Lesage AS, de Loore K, Leysen JE (1996): Risperidone compared with new and reference antipsychotic drugs: in vitro and in vivo receptor binding. Psychopharmacology 124:57-73

Seeman P, Lee T, Chau-Wong M, Wong K (1976): Antipsychotic drug doses and neuroleptic/dopamine receptors. Nature 261:717-719

Sokoloff P, Schwartz JC (1995): Novel dopamine receptors half a decade later. Trends Pharmacol Sci 16:270-275

Strupczewski JT, Bordeau KJ, Chang Y, Glamkowski EJ, Conway PG, Corbett R, Hartman HB, Szewczak MR, Wilmot CA, Helsley GC (1995): 3-[[(Aryloxy)alkyl]piperidinyl]-1,2-benzisoxazoles as $\mathrm{D}_{2} / 5-\mathrm{HT}_{2}$ antagonists with potential atypical antipsychotic activity: antipsychotic profile of iloperidone (HP 873). J Med Chem 38:1119-1131

Szewczak MR, Corbett R, Rush DK, Wilmot CA, Conway PG, Strupczewski JT, Cornfeldt M (1995): The pharmacological profile of iloperidone, a novel atypical antipsychotic agent. J Pharmacol Exp Ther 274:1404-1413

Taylor DM, Duncan-McConnell D (2000): Refractory schizophrenia and atypical antipsychotics. J Psychopharmacol 14:409-418

Truffinet $\mathrm{P}$, Tamminga CA, Fabre LF, Meltzer HY, Rivière M-E, Papillon-Downey C (1999): Placebo-controlled study of the $\mathrm{D}_{4} / 5-\mathrm{HT}_{2 \mathrm{~A}}$ antagonist fananserin in the treatment of schizophrenia. Am J Psychiatr 156:419-425 
Usiello A, Baik J-H, Rouge-Pont F, Picetti R, Dierich A, Lemeur M, Piazza PV, Borrelli E (2000): Distinct functions of the two isoforms of dopamine $D_{2}$ receptors. Nature 408:199-203

Van Tol HM, Bunzow JR, Guan H-C, Sunahara RK, Seeman P, Niznik HB, Civelli O (1991): Cloning of the gene for a human dopamine $\mathrm{D}_{4}$ receptor with high affinity for the antipsychotic clozapine. Nature 350:610-614

Vollenweider FX, Vollenweider-Scherpenhuyzen MFI, Bäbler A, Vogel H, Hell D (1998): Psilocybin induces schizophrenia-like psychosis in human via a serotonin2 agonist action. NeuroReport 9:3897-3902
Vollenweider FX, Vontobel P, Hell D, Leenders KL (1999): 5-HT Modulation of dopamine release in basal ganglia in psilocybin-induced psychosis in man-A PET study with [ $\left.{ }^{11} \mathrm{C}\right]$ raclopride. Neuropsychopharmacol 20:424-433

Wahlbeck K, Cheine M, Essali A, Adams C (1999): Evidence of clozapine's effectiveness in schizophrenia: a systematic review and meta-analysis of randomized trials. Am J Psychiatry 156:990-999

Willner P (1997): The dopamine hypothesis of schizophrenia: current status, future prospects. Int Clin Psychopharmacol 12:297-308 